\title{
How does Academic Performance Increase Virtual Popularity? A Case of Facebook Usage among Indian College Students
}

\author{
Saurabh Maheshwari \\ Sikkim University, Gangtok, India \\ ORCID: 0000-0001-5948-6541 \\ Tuheena Mukherjee \\ Indian Institute of Foreign Trade, New Delhi, India \\ ORCID: 0000-0001-8639-735X
}

Received: 18 Mar 2020

Accepted: 27 Jul 2020

\begin{abstract}
The debate on the positive and negative impact of Facebook on youth particularly on their academic performance has become prevalent in academic discourses. The previous studies show mixed findings of the effect of Facebook on academic performance as well as on other education-related variables. Though the role of Facebook in academics is well explored, however, the impact of academics on Facebook usage has not been examined. The present study examines the reverse possibility i.e. effect of study and academic performance on Facebook usage. Two offline survey studies were conducted on Indian college students. Study one was conducted on 250 undergraduate students (mean age $=20.15 ; 101$ female participants) which shows a significant positive impact of past academic performance on Facebook friendship. Study two was conducted on 317 undergraduate students (mean age $=19.95 ; 259$ females) with two additional indicators of Facebook usage i.e. time spent on Facebook and attitude toward Facebook use. Results of study two also show a positive impact of academic performance on Facebook friendship, however, no such impact is found for other indicators of Facebook use. Overall research shows academic achievement positively influences the virtual popularity of individuals, especially for college students.
\end{abstract}

Keywords: Facebook, virtual popularity, academic performance, Facebook friendship

\section{INTRODUCTION}

Today, if we look around us, the population in one way or the other has become successful in connecting with the people scattered all around the globe. This fact cannot be denied that the emergence of social networking sites not only has placed itself on the highest of the communicating hierarchy but, in many ways, has grasped the accessibility to an individual's privacy, identity, and the way of life. The present generation sees both the youth and the elderly population engaged in social media at large whilst the youth population, in particular, encompasses the eminent strata. Both the positive (e.g. Brandtzæg, 2012; Ellison, Steinfield, \& Lampe, 2007; Kim \& Lee, 2011; Stefanone, Kwon, \& Lackaff, 2012) and negative impacts (e.g. Christofides, Muise, \& Desmarais, 2009; Rauch, Strobel, Bella, Odachowski, \& Bloom, 2014) of Facebook use are shown on various aspect of youths' lives.

A glaring issue related to the usage of Facebook by students is concerning their academic performances. Previous studies have indicated both positive and negative impacts of Facebook on academic performance (e.g., Kirschner \& Karpinski, 2010; Liu, Kirschner, \& Karpinski, 2017; Marker, Gnambs, \& Appel, 2018; Pasek 
\& Hargittai, 2009) as well as on the other hand, the inclusion of the academic-related activities (Celik, Yurt, \& Sahin, 2015; Grosseck, Bran, \& Tiru, 2011; Junco, 2012; Peeters, 2019). A study by Michikyan, Subrahmanyam, and Dennis (2015), however, has indicated the possibility of a reverse relation, that is, the role of academic performance with the usage of Facebook. The present study uses Michikyan, Subrahmanyam, and Dennis's (2015) work as the framework to explore the role of academic performance on the virtual popularity of the students on Facebook.

Facebook and academics. The research by Kirschner and Karpinski (2010) showed the negative impacts of Facebook usage on the GPA of students. Though it was a correlational study based on a survey done over college students, regardless of that, researchers were able to demonstrate the direction of the relationship. Research by Paul, Baker, and Cochran (2012) that included Facebook, along with other online social networking sites like Myspace, Twitter, etc., had found that time spent on these online networking sites negatively influenced the academic performance of participants. Similarly, Junco (2012) had conducted a study on 1839 college students and had shown that time spent on Facebook was significantly and negatively related to academic performance, but the study found a weak relationship between the time spent on Facebook and the time spent in regards of class preparation (Junco, 2012). In another study, Junco (2011) had found that Facebook use was negatively related to students' engagement but positively related to the time they spend on co-curricular activities.

Similarly, Junco and Cotten (2012) showed that multitasking, which included the usage of Facebook or texting during school work, was negatively related to the students' overall GPA. The possible reasons for why Facebook is negatively associated with academic performance could be due to the view that spending too much time on socializing ought to generate adverse effects on academic performance (Junco, 2012). For example, students who are perhaps the most intensive users of Facebook, those who interact on the platform, play, use it as a source of entertainment (Jacobsen \& Forste, 2011), to express themselves, and maintain their friendships altogether as such are in recognition under time-intensive acts which limit the time available for studying, thus possibly harming their academic performances (Skiera, Hinz, \& Spann, 2015).

However, there is another line of research that emphasizes positive or no role of Facebook uses on academic performance; for instance, Kolek and Saunders (2008) in this regards found no relationship between the two. No adverse impacts were found on the GPA of Facebook users and the non-users in their study (Kolek \& Saunders, 2008). Similarly, Pasek and Hargittai (2009) too found no significant relation between Facebook usage and academic performance in terms of GPA. Their study, however, displayed some positive relation between these two variables. In a panel study Leung (2015) found positive relationship between Facebook use and grades. Yu, Tian, Vogel, and Kwok (2010) had found that Facebook usage did not only influence the students' learning directly, but it also helped them in socializing in their respective colleges, which further had led them towards better learning outcomes.

Grosseck, Bran, and Tiru (2011) had found that university students used Facebook majorly for their social functions and diverse academic activities, which included discussing assignments, lectures, class notes, research resources. In another study, it is found that students used Facebook more in comparison to the faculty members for educational purposes (Roblyer, McDaniel, Webb, Herman, \& Witty, 2010). Mazer, Murphy, and Simonds (2009), in their study, had found that teachers' self-disclosure on Facebook enhanced their credibility and also the motivation of students. One possible explanation of no or limited positive association between Facebook use and academic activities, could be multitasking, i.e., using Facebook with other activities, e.g. during watching television, traveling in a bus. As Junco (2012) showed that time spent on Facebook had a weak relationship between Facebook use and class preparation time, this observation was followed by students who used Facebook, not during their class preparation but some other time. Junco (2011) had also found that using Facebook was positively related to a student's engagement in co-curricular activities. However, research in the sociology of education demonstrated that involvement in co-curricular and cultural activities have a positive impact on academic performance (DiMaggio, 1982; DiMaggio \& Morh, 1985; Orr, 2003). In that case, we see the possibility of an indirect positive impact of Facebook use on academic performance through our involvement in cultural activities. 
These studies show inconclusive and puzzling relations between Facebook usage and academics. On one hand, the studies of Kirschner, and Karpinski (2010), Junco (2011, 2012), Juno and Cotton (2012) show a negative role of involvement in Facebook usage with regards to academic performance. On the other hand, researchers like Pasek, More, and Hargittai (2009), and Kolek and Saunders (2008) show a positive impact of using Facebook over academics. Similarly, the others, too, have demonstrated a positive association between the usage of Facebook and various academic activities (e.g., Yu, Tian, Vogel, \& Kwok, 2010; Grosseck, Bran, \& Tiru, 2011; Roblyer, McDaniel, Webb, Herman, \& Witty, 2010).

Present study. Michikyan, Subrahmanyam, and Dennis's (2015) study showed a negative association between Facebook use and academic performance. However, their study indicates that it is the academic performance that influences us to use Facebook rather than reverse causality. In the present study, we follow the same direction of the association, but the difference rests over exploring the possibility of the academic performance capable of influencing our Facebook friend list. The argument is over the students' past academic performances that will positively influence their number of Facebook friends. Our argument is based on the following rationales- (1) high academic performers are usually popular among peers. Students, especially juniors, usually like to be acquainted with brighter and talented students- not only in the physical world but also in the digital world like- Facebook. While for those who are popular in the physical world, a long list of Facebook followers makes them virtually popular as well, which helps in maintaining their selfesteem (Ellison, Steinfield, \& Lampe; 2007; Gonzales \& Hancock, 2010). (2) Previous studies show an indirect positive impact of the usage of Facebook on academic performance, as an academic discussion, better learning outcomes, school socialization (e.g., Yu, Tian, Vogel, \& Kwok, 2010; Grosseck, Bran, \& Tiru, 2011; Roblyer, McDaniel, Webb, Herman, \& Witty, 2010). Hence, following the same logic, we argue that students do not only use Facebook for their purpose of entertainment but utilize it for educational and informational purposes as well. Therefore, it is presumed that students who ought to remain busy with their studies, there could be a possibility of not getting enough time to explore their physical surroundings, which further lead them of requiring Facebook to provide that information (what is going on in college/institution, activities, program, etc.) and academic materials as well (e.g., lectures, posts, and what is going on in their field if they are a member of any group/society of their filed). (3) The need for belongingness is one of the fundamental needs (Baumeister \& Leary, 1995). In the process of obtaining good GPA and fulfilling the need for achievement, students are mainly required to discipline themselves (Duckworth \& Seligman, 2005), thereby suppressing and sacrificing several needs. The need for belongingness could be one of them. Previous research show that one of the main functions that Facebook serves is towards making us able to gratify our need for belongingness (e.g., Nadkarni \& Hoffman, 2012). Therefore, we argue that once these studious students are successful in satisfying their achievement needs, they are most likely to head towards the need for belongingness, and Facebook presumably stands out to be a perfect platform to do so. (4) Moreover, previous researchers (e.g., Pempek, Yermolayeva, \& Calvert, 2009) had found that students used Facebook when they were bored or free, thereby saving time in order to be used for studies. Therefore, our beliefs are over the nature of Facebook, where a quick look into it can serve as a refreshing break while the study hours rather than considering it as something that can hamper otherwise. Therefore, they are not required to waste their energy by going out, which would also be more time consuming, instead, their preferences to go online and catching up with the Facebook activities might work while sitting in their respective rooms. Based on the above arguments we hypothesized that: Academic performance would positively influence the number of friends on Facebook.

\section{STUDY 1}

\section{Methodology}

The present study follows the survey method to understand the relationship between academic performance/involvement and Facebook use, as used in many previous studies (e.g. Grosseck, Bran, \& Tiru, 2011; Junco, 2012; Junco \& Cotton, 2011). However, instead of going for an online survey, we opted for offline survey (e.g. Kirschner \& Karpinski, 2010; Pasek \& Hargittai, 2009) since most of the colleges did not provide institutional email id to students. 
Table 1. Descriptive and bivariate analysis

\begin{tabular}{lccccccccc}
\hline & Mean & SD & 1 & 2 & 3 & 4 & 5 & 6 \\
\hline 1. Age & 20.152 & 1.113 & -- & & & & & & \\
2. Number of Siblings & 1.728 & 1.029 & -.058 & -- & & & & \\
3. Family annual income & 7738.7 & 7370.9 & -.007 & $-.156^{*}$ & -- & & & \\
4. Study hours & 4.515 & 2.533 & $.159^{*}$ & -.072 & .119 & -- & & \\
5. Numbers of Facebook friends & 243.868 & 178.26 & .018 & $-.213^{* *}$ & $.298^{* * *}$ & .021 & -- & & \\
6. Class $10^{\text {th }} \mathrm{GPA}$ & 8.056 & 1.030 & .116 & -.106 & $.146^{*}$ & $.272^{* * *}$ & $.338^{* * *}$ & & \\
7. Class $12^{\text {th }} \mathrm{GPA}$ & 7.961 & 1.097 & .072 & $-.139^{*}$ & $.251^{* *}$ & $.382^{* * *}$ & $.386^{* * *}$ & $.664^{* * *}$ & -- \\
\hline$*$
\end{tabular}

$* \mathrm{p}<.05, * * \mathrm{p}<.01, * * * \mathrm{p}<.001$. Family annual income was reported in INR, but here it is converted in US\$ (@70 INR)

Participants. Data were collected on 250 undergraduate students from various colleges based in New Delhi, India. A total of 149 males and 101 females participated in the study. Age ranged from 19-22 with the mean age of 20.15 years. A total of 101 participants belonged from the rural area, and 149 were from the urban area. Around 90 percent of participants were Hindu, and remaining were Christian, Muslim, and Sikh.

Measures. Self-reported GPA were obtained from class $10^{\text {th }}$ and $12^{\text {th }}$ as indicators of academic performances. The class $10^{\text {th }}$ and $12^{\text {th }}$ levels are considered significant in qualifying examinations under the Indian academic schooling system and are recognized as the most critical parameter for higher studies. Moreover, the participants were undergraduate students; therefore, their past academic performance led to the assumption of being a better parameter to understand the relationship between their Facebook friends and their academics.

Participants were asked to report the number of friends they had on Facebook. Demographic variables such including - age, gender, religion, background in regards to rural or urban, and the number of siblings were also enquired.

Procedure. An offline survey was conducted on college students. With the permission of class instructors, the survey data was collected in a classroom setting. The method of survey was self-administrable. The purpose was briefly introduced in the beginning, and they were debriefed in detail at the end. The survey was purely voluntary, and participants gave their written consent for participation. The analysis used only Facebook users and the ones found not using it; their data were not considered in the study.

\section{Results and Discussion}

Descriptive statistics and bivariate correlations are given in Table 1. Results show that the number of siblings is negatively correlated with the number of Facebook friends. It displays the relation with siblings that acted as a substitution for being associated with a long list of friends. This result collates with the work of Nadkarni, and Hofmann, (2012), which states that Facebook fulfills one's need for belongingness. As assumed, the number of Facebook friends shows a significant positive relation with class $10^{\text {th }}$ and $12^{\text {th }} \mathrm{GPA}$. The results align with previous work which shows a positive relation between Facebook use and academic achievement (Kirschner \& Karpinski, 2010). While the age of participants shows no relationship with academic performance and Facebook friendship, family annual income shows a positive relationship with both the variables. This shows the enabling environment in terms of financial comfort, not only helped in the educational outcome but in social/relational outcomes. Interestingly, in contrast to Junco (2012), in the present research, study hours show no relationship with Facebook use, which shows that students might be using Facebook in their non-study hours.

To examine the impact of the academic performance on Facebook friendship, hierarchical regression analysis is run. The data follows the precondition of regression analysis, such as continuous dependent variable, linear relations between variables, absence of multicollinearity, etc. Table 2 shows the results of the regression analysis in which three models/blocks are used. Model 1 shows the impact of demographic variables on the number of Facebook friends. Results of Model 1 show that the number of siblings, background and family annual income are significant predictors of the number of Facebook friends. The number of siblings negatively predicts Facebook friendship, that is, more siblings at home leads to fewer friends on Facebook. 
Table 2. Hierarchical regression analysis

\begin{tabular}{lccc}
\hline & \multicolumn{3}{c}{ Numbers of Facebook friends } \\
\hline Gender $^{\#}$ & Model 1 & Model 2 & Model 3 \\
Age & .022 & .022 & .016 \\
Number of siblings & -.004 & -.004 & -.021 \\
Background\#\# & $-.158^{*}$ & $-.158^{*}$ & $-.150^{*}$ \\
Family annual income & $.161^{*}$ & $.161^{*}$ & $.156^{*}$ \\
Study hours & $.224^{* * *}$ & $.224^{* *}$ & .138 \\
Class 10 & & -.001 & $-.184^{*}$ \\
Class $12^{\text {th }} \mathrm{GPA}$ & & & .140 \\
$\mathrm{R}^{2}$ & & & $.357^{* * *}$ \\
$\mathrm{R}^{2}$ Change & .147 & .147 & .319 \\
$\mathrm{~F}$ & --- & .000 & $.171^{* * *}$ \\
\hline
\end{tabular}

${ }^{*} \mathrm{p}<.05, * * \mathrm{p}<.01, * * * \mathrm{p}<.001$. Values quoted are $\beta$ values. ${ }^{\#}$ Male $=0$ and Female $=1 ;{ }^{\# \#}$ Rural $=0$ and Urban $=1$

However, Family annual income positively predicts Facebook friendship, which means financial conditions make people even virtually popular. Gender, and age, have shown no role in Facebook Friendship. Model 2 includes study hours in the regression analysis. Results indicate that study hours have no significant impact on Facebook friendship. Model 3 includes demographic variables, study hours, and the academic grades, wherein the results reveal a significant influence of their academic GPA, i.e., the class $12^{\text {th }}$ GPA on the number of Facebook friends. The number of siblings still influences Facebook friends, showing the importance of online friends, especially when low human density at home is compelling towards a higher density over Facebook, hence compensating for the social need. Moreover, results show that students from urban background have more Facebook friends than from rural background. Table 2 also show that there is no direct relation between the number of friends on Facebook and the study hours (see Model 2 of Table 2), but an indirect relation emerges in Model 3 when we entered the academic grade in the prediction model. Model 3 is in support of the hypothesis. As predicted, academic performances show a significant influence on Facebook usage. Results show that Facebook friendship is not only capable of only influencing the academic performances, but rather it is the academic performance that, in reverse, is also capable of influencing the number of friends over Facebook as well.

\section{STUDY 2}

Results of study 1 show that academic performance does influence Facebook friendship. However, the present study goes beyond and considers some more indicators of Facebook usage and relates it to academic achievement. This study helps us to explore the role of academic achievement and different indicators towards our Facebook usage and not only Facebook friendship. It is done to see whether academic performance influence Facebook friendship only or it influences Facebook to use in general. The study also explores the role of smartphones in Facebook use.

\section{Methodology}

The methodology of study two was analogous to study 1, except few changes which are mentioned below.

Participants. A total number of 317 undergraduate students had participated in the study. Out of the 58 were male, and the remaining 259 were females; 72 were from the rural background, and 237 were from the urban background ( 8 did not respond to background information). Ages ranged from 16 to 25 years, with the mean of 19.945 and SD = 1.550 (7 respondents did not disclose their age). Participants were mostly from the Hindu religion.

Measures. We followed Ellison, Steinfield, and Lampe's (2007) Facebook intensity scale, which is widely used in Facebook research. Here, to measure Facebook usage, three indicators were used - time spent on Facebook, the number of Facebook friends, and attitude towards Facebook. Participants were asked the 
Table 3. Descriptive and Bivariate analysis

\begin{tabular}{|c|c|c|c|c|c|c|c|c|c|c|}
\hline & Mean & SD & 1 & 2 & 3 & 4 & 5 & 6 & 7 & 8 \\
\hline 1. Age & 19.95 & 1.55 & -- & & & & & & & \\
\hline 2. Number of siblings & 1.39 & 0.911 & $.185^{* *}$ & -- & & & & & & \\
\hline 3. Family annual income & 3.57 & 1.59 & $-.189 * *$ & $-.164 * *$ & -- & & & & & \\
\hline $\begin{array}{l}\text { 4. Number of Facebook } \\
\text { friends }\end{array}$ & 456.20 & 350.01 & $-.289 * * *$ & $.128 *$ & $.256 * * *$ & -- & & & & \\
\hline $\begin{array}{l}\text { 5. Time spent on } \\
\text { Facebook }\end{array}$ & 56.00 & 53.42 & -.129 & -.083 & .020 & $.213^{* *}$ & -- & & & \\
\hline $\begin{array}{l}\text { 6. Attitude toward } \\
\text { Facebook }\end{array}$ & 24.63 & 9.05 & $-.244 * * *$ & -.040 & $.127 *$ & $.370 * * *$ & $.337^{* * *}$ & -- & & \\
\hline 7. Class $10^{\text {th }} \mathrm{GPA}$ & 8.299 & 1.196 & $-.401 * * *$ & $-.133^{*}$ & $.313^{* * *}$ & $.252^{* * *}$ & $.156^{*}$ & $.207^{* * *}$ & -- & \\
\hline 8. Class $12^{\text {th }} \mathrm{GPA}$ & 8.459 & 1.038 & $-.541 * * *$ & $-.238 * * *$ & $.323 * * *$ & $.387^{* * *}$ & $.176^{*}$ & $.185^{* *}$ & $.579 * * *$ & -- \\
\hline
\end{tabular}

$* \mathrm{p}<.05, * * \mathrm{p}<.01, * * * \mathrm{p}<.001$

following based on the above-mentioned indicators - 1) How many minutes per day they spent on Facebook; 2) How many friends did they have over Facebook; 3) Their attitude towards Facebook. The attitude was measured through six items, and for the present sample, Cronbach's alpha was found to be .84. Instead of merging these three indicators like intensity scale (Ellison, Steinfield, \& Lampe, 2007), the constructs were separately considered for analysis.

Again, for academic performance class, $10^{\text {th }}$ and $12^{\text {th }}$ GPA were taken. Additionally, that age, gender, religion, the background of participants, the number of siblings, family annual income, and their use of smartphones for Facebook were also enquired. Unlike the first study, here family annual income is measured not in as continuous variable but on a categorical variable. There were seven values measured in INR: $1<50000,2<$ $100000,3<200000,4<500000,5<1000000,6<2000000$, and $7>2000000$.

Procedure. The procedure was analogous to the previous study. A self-explanatory questionnaire was used. Participants were briefly informed about the purpose in the beginning and debriefed at the end of the survey completion. Participation in the survey was purely voluntary, and their written informed constant was taken for participation.

\section{Results and Discussion}

Table 3 shows the results of correlation and descriptive analysis. To see the correlation between various study variables, we have performed Pearson correlation, therefore only continuous variables are taken into analysis. Participants' age is found to be negatively related with the number of Facebook friends and also with attitude towards Facebook use. However, no significant relation is found between the age of the students and the time they spent on Facebook. Results show that older students have fewer Facebook friends and relatively less favorable attitudes towards Facebook use. However, they spend almost an equal time as that of the younger students on Facebook. All the three indicators of Facebook use i.e., the number of Facebook friends, time spent on Facebook, and attitude towards Facebook, are significantly related to each other; however, the relationships among them are not very strong. That reflects that the number of Facebook friends do not very much depend on the time they spent on Facebook or on the attitudes they hold for Facebook use. Nevertheless, all three indicators of Facebook usage show a significant relationship with the class $10^{\text {th }}$ and $12^{\text {th }}$ GPA. However, this relationship is much stronger in the case of Facebook friendship than time spent on Facebook and attitudes towards Facebook use.

Table 4 shows the results of hierarchical regression for the three indicators of Facebook use. The data follows the assumptions of regression analysis, like a continuous dependent variable, linear relationship between variables, absence of multicollinearity, etc. For each Facebook indicator, three regression models were run, while model one includes only demographic variables, model 2 includes demographic and mobile use, and model three includes academic performance additionally. Unlike study one, here no impact of the number 
Table 4. Hierarchical regression analysis

\begin{tabular}{|c|c|c|c|c|c|c|c|c|c|}
\hline & \multicolumn{3}{|c|}{ Number of Facebook Friends } & \multicolumn{3}{|c|}{ Time Spent on Facebook } & \multicolumn{3}{|c|}{ Attitude toward Facebook } \\
\hline & Model 1 & Model 2 & Model 3 & Model 1 & Model 2 & Model 3 & Model 1 & Model 2 & Model 3 \\
\hline Gender $^{\#}$ & -.040 & -.047 & -.061 & -.140 & $-.150^{*}$ & -.144 & $-.180^{*}$ & $-.200 * *$ & $-.181^{* *}$ \\
\hline Age & $-.244 * * *$ & $-.225 * * *$ & -.101 & -.122 & -.094 & -.024 & $-.210 * *$ & $-.154^{*}$ & -.140 \\
\hline Number of siblings & -.062 & -.056 & -.030 & -.073 & -.065 & .053 & .019 & .036 & .035 \\
\hline Background ${ }^{\# \#}$ & -.049 &.- .067 & -.081 & .000 & -.025 & -.087 & .093 & .042 & .038 \\
\hline Family Annual Income & $.217^{* *}$ & $.216^{* *}$ & $.166^{*}$ & .006 & .003 & -.031 & .094 & .088 & .074 \\
\hline Facebook in mobile & & $-.143^{*}$ & -.114 & & $-.203 * *$ & $-.190 * *$ & & $-.410 * * *$ & $-.411 * * *$ \\
\hline Class $10^{\text {th }} \mathrm{GPA}$ & & & .017 & & & .044 & & & .073 \\
\hline Class $12^{\text {th }}$ GPA & & & $.280 * *$ & & & .117 & & & -.024 \\
\hline $\mathrm{R}^{2}$ & .132 & .152 & .198 & .040 & .079 & .092 & .091 & .251 & .254 \\
\hline$R^{2}$ Change & --- & $.020^{*}$ & $.046 * *$ & --- & $.039 * *$ & .013 & --- & $.160 * * *$ & .003 \\
\hline $\mathrm{F}$ & $5.861^{* * *}$ & $5.698 * * *$ & $5.842 * * *$ & 1.555 & 2.352 & 2.352 & $3.860 * *$ & $10.670 * * *$ & $8.053^{* * *}$ \\
\hline
\end{tabular}

${ }^{*} \mathrm{p}<.05,{ }^{* *} \mathrm{p}<.01,{ }^{* * *} \mathrm{p}<.001$. Values quoted are $\beta$ values. ${ }^{*}$ Male $=0$ and Female $=1 ;{ }^{\# \#}$ Rural $=0$ and Urban $=1$, \#\#\# Those who use Facebook in mobile $=1$ and those who do not $=0$

of siblings is found on Facebook friendship. Results show, similar to study one, the number of Facebook friends is significantly predicted by class $12^{\text {th }} \mathrm{GPA}$ and family annual income. Results also showed a significant impact of using mobile phones for Facebook on Facebook friendship, however, this impact disappears when we put the indicators of academic performance. However, the use of mobile phones for Facebook was found to be a significant predictor for the other two indicators of Facebook usage. Though gender did not show any impact on the number of Facebook friends directly; however, it showed an indirect effect in the presence of other study variables. Interestingly, no impact of GPA is found in time spent on Facebook as well on attitude towards Facebook use. This clearly shows that good academic performance does not influence Facebook time or attitude towards Facebook, however, increases the number of Facebook friends, probably by making the person virtually popular.

\section{GENERAL DISCUSSION}

Several studies had presented the positive impacts of Facebook on education-related activities (e.g., Grosseck, Bran, \& Tiru, 2011; Mazer, Murphy, \& Simonds, 2007; Roblyer, McDaniel, Webb, Herman, \& Witty, 2010; Yu, Tian, Vogel, \& Kwok, 2010). However, very few researchers specifically explored the link between Facebook friendship and academic achievement. The results of the present study confirmed that academic achievement and Facebook friendships are positively related. The results are novel because the previous studies had mostly assumed, explored, and had found negative relations between academic performance and Facebook usage. The present study found that the relationship is not always negative, but also can emerge positively (e.g. Leung, 2015; Yu, Tian, Vogel, \& Kwok, 2010). The results flow against the general perception and the previous researches (e.g. Kirschner \& Karpinski, 2010; Junco, 2011, 2012), those of who had stated that Facebook negatively influenced the academic performances.

The results also confirmed our hypothesis that academic achievement will significantly predict the number of Facebook friends. The study is original because of its direction of the relationship. Studies have mostly predicted the impact of Facebook usage on academic achievement (e.g. Grosseck, Bran, \& Tiru, 2011; Junco, 2012; Junco \& Cotton, 2011; Kirschner \& Karpinski, 2010; Pasek \& Hargittai, 2009), very few explored the reverse possibility (Michikyan, Subrahmanyam, \& Dennis, 2015). Possible reasoning for negative relationship between Facebook and academic performance is due to the belief that students tend to spend their study time on Facebook (Junco, 2012). Both studies show that academic performance significantly impacts Facebook friendship. The results of both studies revealed that past academic performances influenced Facebook friendship positively, as many previous pieces of research showed that Facebook was used for the gratification of social needs (e.g., Nadkarni \& Hofmann, 2012; Raacke \& Bonds-Raacke, 2008). The social need or the need to belong is a fundamental need present in all human beings (Baumeister \& Leary, 1995). As several researchers (e.g., Astin, 1984; Chickering \& Gamson, 1987) show that time spent on studies is an 
essential element for excellent academic performance. Therefore, it is logical that those who did well in their examinations spent more time on their studies and had less time to gratify their social needs. The studies show (e.g., Pempek, Yermolayeva, \& Calvert, 2009) that to maintain, develop, and gratify social needs, Facebook as a platform was considered more comfortable and less time-consuming.

Studies also showed that people tend to affiliate more with high achievers. It seemed that good academic performance made people popular and therefore are liked and admired by others. The reason for this can be traced that, people often tend to affiliate with high achievers, because social acceptance by high achievers increases their self-worth. The possibility that achievement affects popularity than popularity affecting achievement has strongly been argued by John and Lewis (1974). Peer effects on peer behaviors have been researched widely (Arcidiacono \& Niccholson, 2001; Betts \& Morrell, 1999; Evans, Oates, \& Schwab, 1992; Gaviria \& Raphael, 2001). However, the criterion of popularity is one of the several measures that affect social networks. Popularity through academic achievement is one of the most robust criteria among adolescents and youths. Therefore, a good GPA leads to more friends on Facebook. It is also found that academic performance does not influence the time participants spent on Facebook as well their attitude towards Facebook uses, which shows performance basically makes people popular, and therefore, they have more friends.

The study also reinforces that Facebook usage does not significantly hamper the time devoted to studies. In study 2 of the present research, more than 70 percent of participants stated that they use mobile phones for Facebooking, which they likely access during non-working hours. In Pempek, Yermolayeva, and Calvert's (2009) study, they had presented that participants reported that they used Facebook to take a break from work or when they got bored. In the same study, a participant reported that "Signing a Facebook wall is a lot easier and less time consuming than picking up the phone to call a friend. Not many in college have the time for that" (Pempek, Yermolayeva, \& Calvert, 2009, p. 231). It shows that Facebook helps in saving time when one is engaged in socialization along with maintaining their social relations. Therefore, the perception that Facebook consumed all the productive time for studies seems like a biased thought.

\section{Conclusion, Limitations and Future scope}

The negative image of Facebook is highly questionable. Though Facebook has several negative influences on its users at the same time, its favorable influences on its users are also plenty. More experiments or longitudinal studies would provide a better understanding of the direction of this relation. The study shows that past academic performance significantly and positively influences Facebook usage. The popularity of Facebook is very much visible among high performers who use Facebook as a platform to gratify their social needs.

The first limitation is that the students have provided self-reported measures of their GPA. A more authentic source for their obtained GPA would have been from the school and college records. The second limitation is that in study 2 , the sample is skewed towards the female population. A more balanced sample would have provided a better understanding of gender differences. The future scope of the present study is the crosscultural validation of the study. The present study has the scope of generalization only in the context of the Indian sample. More studies are required to understand the virtual popularity of youths on various social media platforms and the reasons behind that.

\section{REFERENCES}

Arcidiacono, P., \& Nicholson, S. (2001). Peer effects in medical school. Journal of Public Economics, 89(2-3), 327-350. https://doi.org/10.1016/j.jpubeco.2003.10.006

Astin, A. (1984). Student involvement: A developmental theory for higher education. Journal of College Student Personnel, 25(4), 297-308. 
Baumeister, R. F., \& Leary, M. R. (1995). The need to belong: Desire for interpersonal attachments as a fundamental human motivation. Psychological Bulletin, 117(3), 497-529. https://doi.org/10.1037/0033-2909.117.3.497

Betts, J. R., \& Morrell, D. (1999). The determinants of undergraduate grade point average: The relative importance of family background, high school resources and peer group effects. Journal of Human Resources, 34(2), 268-293. https://doi.org/10.2307/146346

Brandtzæg, P. B. (2012). Social networking sites: Their users and social implications - A longitudinal study. Journal of Computer-Mediated Communication, 17(4), 467-488. https://doi.org/10.1111/j.10836101.2012.01580.x

Chickering, A. W., \& Gamson, Z. F. (1987). Seven principles for good practice in undergraduate education. AAHE Bulletin, 39(7), 3-7.

Christofides, E., Muise, A., \& Desmarais, S. (2009). Information disclosure and control on Facebook: are they two sides of the same coin or two different processes? Cyberpsychology \& Behavior, 12(3), 341-345. https://doi.org/10.1089/cpb.2008.0226

Celik, I., Yurt, E., \& Sahin, I. (2015). A Model for Understanding Educational Facebook Use. Eurasia Journal of Mathematics, Science and Technology Education, 11(4), 899-907. https://doi.org/10.12973/eurasia.2015.1447a

DiMaggio, P. (1982). Cultural capital and school success: The impact of status culture participation on the grades of U.S. high school students. American Sociological Review, 47(2), 189-201. https://doi.org/10.2307/2094962

DiMaggio, P., \& Mohr, J. (1985). Cultural capital, educational attainment, and marital selection. American Journal of Sociology, 90(6), 1231-1261. https://doi.org/10.1086/228209

Duckworth, A. L., \& Seligman, M. E. (2005). Self-discipline outdoes IQ in predicting academic performance of adolescents. Psychological Science, 16(12), 939-944. https://doi.org/10.1111/j.14679280.2005.01641.x

Ellison, N. B., Steinfield, C., \& Lampe, C. (2007). The benefits of Facebook "friends:" Social capital and college students' use of online social network sites. Journal of Computer-Mediated Communication, 12(4), 1143-1168. https://doi.org/10.1111/j.1083-6101.2007.00367.x

Evans, W. N., Oates, W. E., \& Schwab, R. M. (1992). Measuring peer group effects: A study of teenage behavior. Journal of Political Economy, 100(5), 966-991. http://www.jstor.org/stable/2138631

Gaviria, A., \& Raphael, S. (2001). School-based peer effects and juvenile behavior. Review of Economics and Statistics, 83(2), 257-268. https://doi.org/10.1162/00346530151143798

Gonzales, A. L., \& Hancock, J. T. (2010). Mirror, mirror on my Facebook wall: Effects of exposure to Facebook on self-esteem. Cyberpsychology Behavior and Social Networking, 14(1-2), 79-83. https://doi.org/10.1089/cyber.2009.0411

Grosseck, G., Bran, R., \& Tiru, L. (2011). Dear teacher, what should I write on my wall? A case study on academic uses of Facebook. Procedia Social and Behavioral Sciences, 15, 1425-1430. https://doi.org/10.1016/j.sbspro.2011.03.306

Jacobsen, W. C., \& Forste, R. (2011). The wired generation: Academic and social outcomes of electronic media use among university students. Cyberpsychology, Behavior, and Social Networking, 14(5), 275-280. https://doi.org/10.1089/cyber.2010.0135

Junco, R. (2011). The need for student social media policies. Educause Review, 46(1), 60-61. 
Junco, R. (2012). Too much face and not enough books: The relationship between multiple indices of Facebook use and academic performance. Computers in Human Behavior, 28(1), 187-198. https://doi.org/10.1016/j.chb.2011.08.026

Junco, R., \& Cotten, S. R. (2011). Perceived academic effects of instant messaging use. Computers \& Education, 56(2), 370-378. https://doi.org/10.1016/j.compedu.2010.08.020

Kim, J., \& Lee, J. E. R. (2011). The Facebook paths to happiness: Effects of the number of Facebook friends and self-presentation on subjective well-being. Cyberpsychology, Behavior, and Social Networking, 14(6), 359-364. https://doi.org/10.1089/cyber.2010.0374

Kirschner, P. A., \& Karpinski, A. C. (2010). Facebook and academic performance. Computers in Human Behavior, 26(6), 1237-1245. https://doi.org/10.1016/j.chb.2010.03.024

Kolek, E. A., \& Saunders, D. (2008). Online disclosure: An empirical examination of undergraduate Facebook profiles. Journal of Student Affairs Research and Practice, 45(1), 1-25. https://doi.org/10.2202/19496605.1905

Leung, L. (2015). A panel study on the effects of social media use and internet connectedness on academic performance and social support. International Journal of Cyber Behavior, Psychology and Learning, 5(1), 1-16. https://doi.org/10.4018/ijcbpl.2015010101

Liu, D., Kirschner, P. A., \& Karpinski, A. C. (2017). A meta-analysis of the relationship of academic performance and Social Network Site use among adolescents and young adults. Computers in Human Behavior, 77, 148-157. https://doi.org/10.1016/j.chb.2017.08.039

Marker, C., Gnambs, T., \& Appel, M. (2018). Active on Facebook and failing at school? Meta-analytic findings on the relationship between online social networking activities and academic achievement. Educational Psychology Review, 30(3), 651-677. https://doi.org/10.1007/s10648-017-9430-6

Mazer, J. P., Murphy, R. E., \& Simonds, C. J. (2007). I'll see you on "Facebook": The effects of computermediated teacher self-disclosure on student motivation, affective learning, and classroom climate. Communication Education, 56(1), 1-17. https://doi.org/10.1080/03634520601009710

Mazer, J. P., Murphy, R. E., \& Simonds, C. J. (2009). The effects of teacher self disclosure via Facebook on teacher credibility. Learning, Media and Technology, 34(2), 175-183. https://doi.org/10.1080/17439880902923655

Michikyan, M., Subrahmanyam, K., \& Dennis, J. (2014). Can you tell who I am? Neuroticism, extraversion, and online self-presentation among young adults. Computers in Human Behavior, 33, 179-183. https://doi.org/10.1016/j.chb.2014.01.010

Nadkarni, A., \& Hofmann, S. G. (2012). Why do people use Facebook? Personality and Individual Differences, 52(3), 243-249. https://doi.org/10.1016/j.paid.2011.11.007

Orr, A. J. (2003). Black-White differences in achievement: The importance of wealth. Sociology of Education, 76(4), 281-304. https://doi.org/10.2307/1519867

Pasek, J., \& Hargittai, E. (2009, May 4). Facebook and academic performance: Reconcilling a media sensation with data. First Monday, 14(5). https://doi.org/10.5210/fm.v14i5.2498

Paul, J. A., Baker, H. M., \& Cochran, J. D. (2012). Effect of online social networking on student academic performance. Computers in Human Behavior, 28(6), 2117-2127. https://doi.org/10.1016/j.chb.2012.06.016

Peeters, W. (2019). The peer interaction process on Facebook: A social network analysis of learners' online conversations. Education and Information Technologies, 24(5), 3177-3204. https://doi.org/10.1007/s10639-019-09914-2 
Pempek, T. A., Yermolayeva, Y. A., \& Calvert, S. L. (2009). College students' social networking experiences on Facebook. Journal of Applied Developmental Psychology, 30(3), 227-238. https://doi.org/10.1016/j.appdev.2008.12.010

Raacke, J. \& Bonds-Raacke, J. (2008). MySpace and Facebook: Applying the uses and gratifications theory to exploring friend-networking sites. Cyberpsychology \& Behavior, 11(2), 169-174. https://doi.org/10.1089/cpb.2007.0056

Rauch, S. M., Strobel, C., Bella. M., Odachowski, Z., \& Bloom C. (2014). Face to face versus Facebook: Does exposure to social networking web sites augment or attenuate physiological arousal among the socially anxious? Cyberpsychology, Behavior, and Social Networking, 17(3), 187-190. https://doi.org/10.1089/cyber.2012.0498.

Roblyer, M. D., McDaniel, M., Webb, M., Herman, J., \& Witty, J. V. (2010). Findings on Facebook in higher education: A comparison of college faculty and student uses and perceptions of social networking sites. The Internet and Higher Education, 13(3), 134-140. https://doi.org/10.1016/j.iheduc.2010.03.002

Skiera, B., Hinz, O., \& Spann, M. (2015). Social media and academic performance: Does the intensity of Facebook activity relate to good grades? Schmalenbach Business Review, 67(1), 54-72. http://search.proquest.com/docview/1650149343?pq-origsite=gscholar

Stefanone, M. A., Kwon, K. H, \& Lackaff, D. (2012). Exploring the relationship between perceptions of social capital and enacted support online. Journal of Computer-Mediated Communication, 17(4), 451-466. https://doi.org/10.1111/j.1083-6101.2012.01585.x

Yu, A. Y., Tian, S. W., Vogel, D., \& Kwok, R. C. (2010). Can learning be virtually boosted? An investigation of online social networking impacts. Computer \& Education, 55(4), 1494-1503. https://doi.org/10.1016/j.compedu.2010.06.015

Correspondence: Saurabh Maheshwari, Sikkim University, Gangtok, India. E-mail: mahesaurabh@gmail.com 